80 Literatura e Sociedade

\title{
REALISMO E SÁTIRA NAS RECORDAÇÕES dO ESCRIVÃo ISAías CAMINHA
}

\author{
Irenísia ToRres de Olivelra \\ Universidade Federal do Ceará
}

Resumo

Este artigo discute a mistura de realismo e sátira no romance Recordações do escrivão Isaías Caminha, de Lima Barreto, publicado em 1909. A coexistência dos dois gêneros no romance tendeu a ser considerada pela crítica um defeito de composição, com prejuízos graves à unidade narrativa. Propõe-se aqui examinar este desacerto em relação àquele outro identificado por Roberto Schwarz em Senhora, também caracterizado pela dualidade de tons e a ruptura de unidade, articulando as dificuldades formais de desenvolvimento da história de Isaías ao problema de longo curso da literatura brasileira de tratar as realidades locais no modelo de romance europeu.

\section{Abstract}

This article discusses the mixture of realism and satire in Lima Barreto's novel Recordações do escrivão Isaías Caminha, published in 1909. The coexistence of the two genres in the novel tended to be considered by the critic as a composition fault, with serious damages to the narrative unity. It is proposed here to examine such disagreement in relation to that one identified by Roberto Schwarz in the novel Senhora, both characterized by the duality of tones and the disruption of unity, articulating formal development difficulties of Isaias' story to the long term problem of Brazilian literature to treating local realities in European model of novel.

Palavras-chave

Realismo;

Sátira;

Recordações do escrivão Isaías

Caminha;

Lima Barreto.

Keywords

Realism; Satire; Recordações do escrivão

Isaías

Caminha;

Lima Barreto. 
"Afortunados os tempos para os quais o céu estrelado é o mapa dos caminhos transitáveis e a serem transitados, e cujos rumos a luz das estrelas ilumina. Tudo lhes é novo e no entanto familiar, aventuroso e no entanto próprio. O mundo é vasto e no entanto é como a própria casa, pois o fogo que arde na alma é da mesma essência que as estrelas."

(G. Lukács, A teoria do romance: um ensaio histórico-filosófico sobre as formas da grande épica).

A

intenções realistas de Lima Barreto provavelmente levaram-no ao roman à clef e à sátira, portanto a procedimentos com intenção mimética, mas que atuam sobretudo pela distorção. Em parte, a relação direta com o representado deve ter sido desejada por Lima Barreto, como forma de intervir no presente e nas situações concretas que o rodeavam, não permitindo aos contemporâneos reduzir seus escritos a alguma espécie de reflexão geral e distante sobre a humanidade, como ele via acontecer com Machado de Assis. "Imitando" pessoas conhecidas, não deixava dúvidas de que queria falar do que estava acontecendo naquele momento. ${ }^{1}$ A crítica da época viu nisso um sinal de fraqueza, a autocondenação de um livro que tinha méritos - as Recordações do escrivão Isaías Caminha -, ao circunstancial e provisório. ${ }^{2}$ Como se sabe, Lima Barreto ganhou a aposta de seus contemporâneos, ao sustentar que o romance, publicado em 1909, permaneceria mesmo depois de desaparecidas as pessoas satirizadas.

Entretanto, permaneceria também a desconfiança da crítica sobre a presença da sátira nas Recordações. Chamo a atenção para a análise cuidadosa de Lúcia

1 "The wide popularity and stubborn persistence of the roman à clef [...] suggests that, far from being an sclerotic form, it continues to energize the imagination of readers and writers unable or unwilling to accept the novel's isolation from the world of fact" (cf, Sean Latham, The art of scandal: Modernism, libel law and roman à clef, New York, Oxford University Press, 2009, p. 10).

2 "Perdoe-me o pedantismo, mas a arte, a arte que o senhor tem capacidade para fazer, é representação, é síntese, é, mesmo realista, idealização. Não há um só fato literário que me desminta. A cópia, a reprodução, mais ou menos exata, mais ou menos caricatural, mas que se não chega a fazer a síntese de tipos, situações, estados d'alma, a fotografia literária da vida, pode agradar à malícia dos contemporâneos que põem um nome sobre cada pseudônimo, mas, escapando à posteridade, não a interessando, fazem efêmero e ocasional o valor das obras" (cf. Carta de José Veríssimo, in Lima Barreto, Correspondência ativa e passiva, São Paulo, Brasiliense, 1956, t. 1, v. XVI, p. 204). Além dessa carta, houve críticas mais ácidas nos jornais: de Medeiros e Albuquerque (A Notícia, 1909), Alcides Maia (Diário de Notícias, 1909) e, alguns anos mais tarde, João Ribeiro (O Imparcial, 1917). 
Miguel-Pereira, que valoriza muito a obra de Lima Barreto, ${ }^{3}$ mas aponta defeitos no romance. Para ela, o escritor fazia romance na primeira parte e sátira na segunda. Enquanto a metade inicial primava pela análise fina e a introspecção, a última entregava-se ao traço pesado e à caricatura. Era um livro desigual, como o definira o próprio autor em carta a um amigo. Se conseguira fundir, pelo poder criador, a capacidade de análise e o senso poético, os quais possuía em alto grau, fizera também conviver ali duas formas inconciliáveis, o realismo e a sátira. "Na verdadeira sátira há um fator idealista, uma transposição da realidade que não lhe permite sofrer o contacto com a observação direta dos fatos e dos caracteres sem se transformar em caricatura superficial e vulgar, sem restringir o seu alcance." ${ }^{\prime 4}$ Lúcia Miguel reconhece em Lima Barreto "essa solidariedade informulada, instintiva, essa capacidade de fazer eco a todas as dores", ${ }^{5}$ comum a todo grande romancista, mas lamenta nele a tendência caricatural, que perturba a grandeza daqueles sentimentos e promove "um deliberado amesquinhamento da vida", ${ }^{6}$ No Triste fim de Policarpo Quaresma, por exemplo, a sátira tinha sido capaz de superar a inumanidade da caricatura por uma visão de dentro das personagens. D. Quixote seria o modelo da verdadeira sátira, onde se fundiam "emoção e julgamento".

Pelo que me lembro, a mistura de sátira e introspecção (às vezes uma seriedade inesperada) encontra-se em quase tudo que Lima Barreto escreveu, inclusive no Triste fim. Nesse, a distância narrativa varia desde uma perspectiva mais distante, aquela que olha de cima, até outra que está no mais íntimo das personagens. A simpatia suaviza realmente a sátira, como avalia Lúcia Miguel, mas não deixa de haver ali, de uma personagem para outra, certas oscilações de distância que não passam despercebidas ao leitor. Percebe-se o mesmo no romance Vida e morte de M. J. Gonzaga de Sá, que pende para o lado da confissão mas não deixa de ter seus momentos de sátira desabusada, principalmente contra a burocracia.

Diante da diferença de tons (confessional e satírico) existente nas Recordações, e percebida por vários críticos como defeito de composição, ${ }^{8}$ este artigo propõe

\footnotetext{
${ }^{3}$ Para Lúcia Miguel-Pereira, a obra de Lima Barreto é, "incontestavelmente, um elo entre o romance machadiano e as atuais tendências da ficção [o Modernismo]" (Lúcia Miguel-Pereira, Prosa de ficção (1870-1920), Belo Horizonte, Itatiaia, São Paulo, Edusp, 1988, p. 275).

${ }^{4}$ Miguel-Pereira, Prosa de ficção (1870-1920), op. cit.,p. 293-4.

${ }_{5}^{5}$ Antonio Candido considera mesmo essa solidariedade como o movimento profundo da prosa de Lima Barreto: "a sua passagem constante da particularidade individual para a generalidade da elaboração romanesca (e vice-versa)" (cf. Antonio Candido, "Os olhos, a barca e o espelho", in A educação pela noite E outros ensaios, 2.ed., São Paulo, Ática, 1989, p. 49).

${ }^{6}$ Lúcia Miguel Pereira, Prosa de ficção (1870-1920), op. cit., p. 292.

${ }^{7}$ Idem, ibidem, p. 294.

${ }^{8}$ Além de Lúcia Miguel, Carlos Nelson Coutinho também considera que, na segunda parte, as Recordações entregam-se à mera descrição e perdem com isso a totalidade abrangente da vida (cf. Carlos Nelson Coutinho, "O significado de Lima Barreto na Literatura Brasileira", in Carlos Nelson Coutinho et al., Realismo e anti-realismo na literatura brasileira, Rio de Janeiro, Paz e Terra, 1974, p. 1-56). Na análise do romance em foco, o autor segue de perto a argumentação desenvolvida em Georg Lukács, "Narrar ou descrever", in Ensaios sobre literatura, trad. Giseh Vianna Konder, Rio de Janeiro, Civilização Brasileira, 1967, p. 47-99.
} 
refletir sobre a possibilidade de que tal desacerto tenha relação com aquele outro apontado por Roberto Schwarz no romance Senhora, de José de Alencar. ${ }^{9}$ Trata-se ali também de um desacerto de tons, ora grandiloquente, ora bonachão, no qual o crítico aponta um desencontro mais profundo, com raízes na vida ideológica do país. Os valores na obra de Lima Barreto são diferentes muitas vezes e outras variáveis estão presentes, mas é possível que ainda aqui o problema tenha se reproposto. Uma vez que isso se evidencie, interessa naturalmente pensar os novos elementos e circunstâncias em jogo.

$\mathrm{Na}$ análise de Senhora, Schwarz explica que o desacerto aparece, em termos literários, como um problema de unidade: o problema formal resultava duma combinação ideológica normal no Brasil submetida à exigência de unidade própria ao romance realista e à literatura moderna. Alencar pretendera trazer para o romance tanto os grandes temas do romance europeu ("a carreira social, a força dissolvente do dinheiro, o embate de aristocracia e vida burguesa, o antagonismo entre amor e conveniência, entre vocação e ganha-pão"10), quanto as figuras da vida cotidiana brasileira, regidas pelo favor. Para ser fiel a esses dois sistemas (conflitos próprios à forma do romance e sociedade brasileira), Alencar os representa cuidando de diferenciar os tons em que aparecem. Assim, no centro, onde se passa o conflito propriamente europeu, universal (amor versus dinheiro), o tom é reflexivo e problemático; e, na periferia, onde se encontra a população peculiarmente brasileira (famílias irregulares, comadres, sinhazinhas, agregados), o tom é desafogado e bonachão. O princípio de composição (valores liberais, a dignidade do indivíduo) valia apenas para o conflito nuclear, mas não para a periferia. "O aspecto programático dos sofrimentos dela [Eugênia], que lhes deveria avalizar a dignidade mais que pessoal, faz efeito de veleidade isolada, de capricho de moça." 11 O predomínio formal, portanto, não correspondia ao peso social dessas esferas. Formalmente, o privilégio era do enredo mas Alencar não materializava esse privilégio, pois não criticava a ordem do favor, a qual na verdade apreciava. Forma europeia e sociabilidade local contradiziam-se em princípio, mas essa contradição não tinha consequências no romance justamente pelo senso de realidade de Alencar, afinal, de fato, ambas conviviam na sociedade brasileira e a esfera européia existia aqui efetivamente, mas modificada. Para fazê-las atuar em sistema, ou seja, submetendo-as ao mesmo princípio de composição e unidade formal, seria preciso descobrir o seu "sistema de modificações", a lógica da convivência de ideias liberais e sociedade clientelista no Brasil. Machado de Assis encontrara a solução para o desacerto, ao trazer a população periférica do romance de Alencar para o centro, fazendo coincidir predominância formal e social, e ao tomar o desacerto como ponto de partida. O que antes aparecia como resultado, agora era pressuposto. Na fase madura de Machado, o desacordo entre ideias e práticas impregnava

${ }^{9}$ A análise de Senhora encontra-se em Roberto Schwarz, Ao vencedor as batatas: forma literária e processo social nos inícios do romance brasileiro, São Paulo, Duas Cidades, Ed. 34, 2000.

${ }^{10}$ Idem, ibidem, p. 37-8.

${ }^{11}$ Idem, ibidem, p. 62. 
cada frase, não mais como efeito inevitável e indesejado, mas como resultado histórico incorporado à forma, na clave do humor e do sarcasmo. ${ }^{12}$ Espero ter resumido adequadamente os pontos-chave da argumentação de Schwarz, para os fins aqui propostos, que são os de refletir sobre o romance de Lima Barreto, articulando-o a um problema de longo curso do romance brasileiro em sua relação com o modelo europeu.

Em meio à literatura autossatisfeita do início do século XX, extremamente convencionalizada nos conflitos e linguagem, Lima Barreto chega ao problema que nos interessa buscando "tratar as grandes questões do tempo" e retomando, para isso, a tradição crítica do romance europeu. A motivação da escrita das Recordações, declarada num texto inicial chamado "Breve notícia", é desmentir a tese lida em um artigo de revista, segundo a qual os mulatos, mesmo quando tinham um começo de vida promissor, terminavam por fracassar, devido à falta de energia característica da raça. Isaías, ele mesmo afetado por tal prognóstico, resolve contar sua história para mostrar que tais insucessos não se deviam a fatores fisiológicos ("não estava em nós, na nossa carne, no nosso sangue"), mas a constrangimentos sociais. A intenção, portanto, era mostrar que a responsabilidade do fracasso estava na sociedade e não no indivíduo.

Não é meu propósito também fazer uma obra de ódio; de revolta, enfim; mas uma defesa a acusações deduzidas superficialmente de aparências cuja essência explicadora, as mais das vezes, está na sociedade e não no indivíduo desprovido de tudo, [...] isolado contra inimigos que o rodeiam. ${ }^{13}$

Com isso, abre-se um romance em primeira pessoa, cuja história remete a um tipo de enredo clássico do romance europeu. O indivíduo ingênuo e arrogante lança-se ao mundo para conquistar os objetivos aparentemente à sua disposição, convencido de ter os méritos e valores suficientes para isso. Com os instrumentos do romance, trazendo à luz o indivíduo em luta contra a sociedade, começa a surgir a distância daquela constituição de indivíduo, que pressupunha o contexto europeu, para as chances reais de individuação numa sociedade paternalista e de dependência pessoal como a brasileira. Em outro artigo, com o título "Uma palha na cidade", procurei pensar justamente a rapidez com que as altas intenções e o orgulho de Isaías são aniquilados sumariamente, diante dos primeiros obstáculos, rastreando a problemática até a fragilidade de sua consciência individual, constituída sobre o lastro precário dos elogios na escola e por um manual de força de vontade. A sátira vigora na falta de inteiriçamento desse personagem, de sua impossibilidade de prolongar o atrito, a tensão dramática, o jogo das ações em que se revelam, no romance europeu, o indivíduo e a sociedade. ${ }^{14}$ Policarpo Quaresma

\footnotetext{
${ }^{12}$ A argumentação completa, aqui muito rapidamente resumida, encontra-se no capítulo II, "A importação do romance e suas contradições em Alencar" (Idem, ibidem, p. 33-79).

${ }^{13}$ Lima Barreto, Recordações do escrivão Isaías Caminha, São Paulo, Brasiliense, 1956, p. 42, v. I, da obra completa.

${ }^{14} \mathrm{O}$ artigo foi publicado na Revista Letras, Curitiba, n. 64, p. 77-89, set.-dez. 2004.
} 
será muito mais obstinado que Isaías, mas essa obstinação, que garante a existência de ações e a revelação de um panorama variado da sociedade brasileira, é uma excentricidade, uma quase loucura, certamente uma alienação.

É possível notar que a história de Isaías, que se muda para a cidade grande, com o objetivo de formar-se e ocupar uma boa posição na sociedade, esse enredo típico do romance europeu, assume um tom sério, reflexivo e confessional, enquanto o meio em volta, com seus doutores e jornalistas, é captado com distância e representado satiricamente. A pergunta da qual parte esse artigo é se o romance de Lima Barreto também separou, como Senhora, a forma de tratar o enredo europeu e a de tratar a sociedade brasileira, inadequada ao modelo. A diferença seria que, agora, as ideias liberais, sobretudo a dignidade do indivíduo, incidem também sobre a "matéria brasileira", com virulência e força crítica, mas ao custo de rebaixar essa matéria, como aponta Lúcia Miguel-Pereira. Entretanto, há ligações entre uma parte e outra que iluminam complexidades tanto dos gêneros narrativos quanto de suas relações com as sociedades representadas.

Para chegar a elas, será preciso acompanhar um pouco a trajetória de Isaías, da maneira como ele a recupera anos depois, de um lugar distanciado. O narrador começa com a explicação da origem de seus anseios de inteligência, os quais atribui à desigualdade de nível intelectual no meio familiar. "O espetáculo do saber de meu pai, realçado pela ignorância de minha mãe e de outros parentes dela, surgiu ao meus olhos como um deslumbramento." O pai, inteligente e ilustrado, impressionava-o com seus conhecimentos e exortações obscuras, enquanto a mãe parecia-lhe triste e humilde porque não sabia dizer os nomes das estrelas, nem explicar a ocorrência da chuva. Na primeira recordação do romance, o pai apresenta-o ao modelo mais alto da época:

Você sabe que nasceu quando Napoleão ganhou a batalha de Marengo? Arregalei os olhos e perguntei: quem era Napoleão? Um grande homem, um grande general... E não disse mais nada. Encostou-se à cadeira e continuou a ler o livro. Afastei-me sem entrar na significação de suas palavras; contudo a entonação de voz, o gesto e o olhar ficaram-me eternamente. Um grande homem! ${ }^{15}$

Napoleão será mencionado vários vezes ao longo da narrativa, o que relaciona as Recordações aos valores que cercaram o modelo de romance europeu do século XIX, adotado por Isaías na escrita de sua história. ${ }^{16} \mathrm{~A}$ importância da figura de Napoleão na vida intelectual do século XIX é avaliada por Georg Lukács, em ensaio sobre Dostoiévski, partindo de observações de Emerson, para quem o segredo

${ }^{15}$ Lima Barreto, Recordações do escrivão Isaías Caminha, op. cit., p. 45.

16 "Estão ali O crime e o castigo de Dostoiévski, um volume de contos de Voltaire, A Guerra e a Paz de Tolstói, o Rouge et Noir de Stendhal, a Cousine Bette de Balzac, a Education Sentimentale de Flaubert, o Antéchrist de Renan, o Eça; na estante, sob as minhas vistas, tenho o Taine, o Bouglé, o Ribot e outros autores de literatura propriamente, ou não. Confesso que os leio, que os estudo, que procuro descobrir nos grandes romancistas o segredo de fazer" (cf. Lima Barreto, Recordações do escrivão Isaías Caminha, op. cit., p. 120). 
do influxo napoleônico estaria em que esse "encarnava em si as virtudes e os defeitos de um grande número de homens" de sua época e da subsequente. Balzac e Stendhal teriam procurado justamente as consequências do relacionamento entre o homem e a época, ou seja, entre o modelo de indivíduo espelhado em Napoleão e a sociedade burguesa, submetendo-a a uma espécie de prova:

Esse Napoleão é o símbolo das possibilidades ilimitadas que a inteligência tem na sociedade democrática e, ao mesmo tempo, a verdadeira medida do caráter democrático da sociedade; que revelaria essa medida pelo seu comportamento diante da pergunta: até que ponto nesta determinada sociedade é possível uma carreira napoleônica? ${ }^{17}$

Os dois escritores já reconheciam, entretanto, que o período revolucionário burguês se esgotara. Para Rastignac, Napoleão não aparecia como representante da Revolução Francesa, mas como um exemplo de energia: "Da figura de Napoleão emana um fascínio e ela constitui-se em um modelo, nem tanto pelos fins, onde sua ação é direta mas acima de tudo pelos seus métodos, pela sua maneira de agir, pela sua técnica de superar os obstáculos". ${ }^{18}$ Também para Isaías, Napoleão apresenta-se mais como um exemplo de força interior e êxito, do que propriamente como representante dos conteúdos revolucionários, que, no Brasil republicano, tinham pouca consequência prática.

$\mathrm{Na}$ breve cena inicial, estão dados, portanto, os valores que Isaías irá perseguir ao longo da vida: a figura de Napoleão, como exemplo de grande homem, e a imagem do saber, expressa no livro, como meio para atingi-lo. Reforçando esse conjunto - o pai branco, o livro, a consideração social - o narrador apresenta ainda como influência marcante a professora, Dona Ester:

Correspondi-lhe à afeição com tanta força d'alma, que tive ciúmes dela, dos seus olhos azuis e dos seus cabelos castanhos, quando se casou. Tinha eu então dois anos de escola e doze de idade. Daí a um ano saí do colégio, dando-me ela como recordação, um exemplar do Poder da Vontade, luxuosamente encadernado, com uma dedicatória afetuosa e lisonjeira. Foi o meu livro de cabeceira. ${ }^{19}$

É possível aqui pensar na afinidade entre os papéis que exercem a figura de Napoleão e o livro dado pela professora no romance, ambos funcionando como estímulos a uma individualidade em formação, deslumbrando e seduzindo, mas destituídos de conteúdos específicos e de algum tipo de impregnação ideológica com requisito de coerência. Assim, vencer pelo estudo pode compartilhar, em certo nível de generalidade, com o ponto de partida do romance de Balzac ou Stendhal, que busca testar até que ponto a sociedade é realmente democrática, a depender das "possibilidades ilimitadas da inteligência" e da plausibilidade de uma carreira napoleônica. Se os romances europeus desmentem o caráter preten-

\footnotetext{
${ }^{17}$ Lukács, "Dostoiévski", in Ensaios de literatura, op. cit., p. 157.

${ }^{18} \mathrm{Idem}$, ibidem, p. 158.

${ }^{19}$ Lima Barreto, Recordações do escrivão Isaías Caminha, op. cit., p. 46-7.
} 
samente democrático da sociedade burguesa, o romance de Lima Barreto, que lhes segue com atenção o modelo, alcança também uma visada crítica da sociedade brasileira, mas sofre uma série de dificuldades ligadas à especificidade da matéria, entre as quais a de ceder o passo à sátira em boa parte da narrativa.

Também já de início estabelece-se o contraponto de tudo o que Isaías valoriza, quando criança e quando jovem. Ele quer vencer na vida, indo em direção ao pai que não o reconhecera (o pai é padre, sabe-se depois), mas de cuja imagem fixada na infância ele quer aproximar-se ("Ah! Seria doutor! Resgataria o pecado original do meu nascimento humilde, amaciaria o suplício premente, cruciante e omnímodo de minha cor..."). Pela oposição na qual os pais estão fixados, isso significa não reconhecer-se na mãe, obscura, analfabeta, pobre e negra. No que tem de melhor, o romance conduz esse conflito noutra linha de força, não explícita mas relevante, onde estão em jogo os valores que disputam a consciência em formação do jovem intelectual pobre e mulato. Voltaremos a isso mais tarde.

Com essa série de noções na cabeça, Isaías ainda hesita um pouco entre a pacata vida roceira e as expectativas de triunfos no Rio de Janeiro, até que se decide, de um dia para o outro, pela partida. Inicialmente dispensa qualquer orientação (Não sou eu rapaz ilustrado? Para que conselhos?), mas depois acompanha um amigo da família, misto de agregado e protetor, para conseguir um bilhete do fazendeiro, coronel Belmiro, pedindo ao deputado Castro um emprego, com que se sustentasse no período de estudos. A indiferença inicial de Isaías por esse bilhete contrasta com o peso que assume posteriormente, quando ele já está no Rio de Janeiro, tornando-se praticamente o único recurso do jovem aspirante ao doutorado. Por um bom tempo, Isaías dedica-se exclusivamente a procurar o deputado, na Câmara ou em casa, em vários horários diferentes, sem encontrá-lo. O dinheiro vai acabando e Isaías angustia-se com medo de não poder pagar o hotel, ser preso e cair na miséria, em um lugar onde não possuía amigos, nem nenhuma relação. Nesse momento, revela a esperança que colocara no bilhete: "Saíra de meus penates, cheio de entusiasmo, certo de que aquela carta, mal fosse apresentada, me daria uma situação qualquer. Essa era a minha convicção, dos meus e do próprio coronel". ${ }^{20}$

$\mathrm{Na}$ mesma ocasião, o dinheiro, como entidade suplementar à proteção que falha, surge positivamente: "Os meus únicos amigos eram aquelas notas sujas encardidas; eram elas o meu único apoio; eram elas que me evitavam as humilhações, os sofrimentos, os insultos de toda a sorte". ${ }^{21}$ O dinheiro, portanto, não aparece, a exemplo do romance europeu, como uma força dissolvente dos valores e das tradições, mas como uma espécie de sucedâneo anônimo da proteção, capaz de valer a qualquer um. Essa espécie de visão do dinheiro, embora circunstancial no romance, pressupõe uma sociedade ainda não mediada no seu cotidiano por relações estritamente capitalistas, em que o ganho pecuniário tenha vindo a primeiro plano e provocado uma alienação nas relações mais próximas. Naquelas

\footnotetext{
${ }^{20}$ Idem, ibidem, p. 85.

${ }^{21}$ Idem, ibidem, p. 86.
} 
condições, em que a referência de poder ainda é pessoal, o dinheiro subordina-se a essa referência, assumindo a forma de um protetor. "Eu nunca compreendi tanto a avareza como naqueles dias que dei alma ao dinheiro". ${ }^{22}$

Daí a alguns dias, Isaías fica sabendo onde mora de fato o deputado (na casa de uma amante) e vai procurá-lo cheio de esperanças. Mas não é recebido, nem atendido, com a prontidão que esperava. O deputado alega crise, falta de prestígio, recomenda-lhe prestar concurso e, finalmente, condena a busca de proteção:

Houve ocasião em que ele exprobou essa nossa mania de empregos e doutorado, citando os ingleses e os americanos. - Todo o mundo quer ser doutor... Corei indignado e respondi com alguma lógica, que me era impossível romper com ela; se os fortes e aparentados, os relacionados, para a formatura apelavam, como havia eu, mesquinho, semi-aceito, de fazer exceção? ${ }^{23}$

A reivindicação de Isaías, como se percebe, é a igualdade no direito ao favor. Percebe-se aqui uma mescla entre uma postura liberal - uma espécie de dicção liberal - e as condições de poder pessoal efetivamente válidas, que aliás aparece ao longo da narrativa das mais variadas formas. A igualdade que, no contexto europeu, pressupunha a universalidade e a impessoalidade, combina-se, na fala de Isaías, ao pedido de proteção mediado por uma cadeia de relações pessoais. Mas evidentemente a proteção não é para todos, depende de interesses particulares, não controlados pela parte mais fraca. Para justificar a negativa, o deputado lança mão do liberalismo inglês e americano, forçando o individualismo econômico a atuar como ideologia de primeiro grau. ${ }^{24}$ Isaías retruca com a experiência concreta. No fim de tudo, Dr. Castro o engana, mandando-o procurá-lo depois no escritório, quando já está de partida para um período em São Paulo. Isaías sabe isso pelo jornal, no caminho de casa, e tem uma grande reação de revolta. "Hoje que sou um tanto letrado sei que Stendhal dissera que são esses momentos que fazem os Robespierres. O nome não me veio à memória, mas foi isso que eu desejei chegar ser um dia". ${ }^{25}$

Depois disso, acontecem em rápida sucessão dois episódios, que vão tirar as esperanças de Isaías definitivamente. O primeiro é a intimação da polícia por causa de um furto no hotel em que está hospedado. Na delegacia, enquanto espera ser chamado, o jovem observa as pessoas em volta, todas pobres, até que ouve do delegado: "E o caso do Jenikalé? Já apareceu o tal 'mulatinho'?". O tratamento pejorativo desperta em Isaías, como em outras situações ao longo do romance, a consciência do desacordo entre sua visão de si mesmo e a que os outros têm dele.

Não tenho pejo em confessar hoje que quando me ouvi tratado assim, as lágrimas me vieram aos olhos. Eu saíra do colégio, vivera sempre num ambiente artificial de consideração, de

${ }^{22}$ Idem, ibidem.

${ }^{23}$ Idem, ibidem, p. 101.

${ }^{24}$ A noção de "ideologia de primeiro grau" é referida aqui no sentido utilizado por Roberto Schwarz, no ensaio "As idéias fora do lugar", in Ao vencedor as batatas, op. cit., p. 9-31.

${ }^{25}$ Lima Barreto, Recordações do escrivão Isaías Caminha, op. cit., p. 103. 
respeito, de atenções comigo; a minha sensibilidade, portanto, estava cultivada e tinha uma delicadeza extrema que se ajuntava ao meu orgulho de inteligente e estudioso, para me dar não sei que exaltada representação de mim mesmo, espécie de homem diferente do que era na realidade, ente superior e digno a quem um epíteto daqueles feria como uma bofetada. ${ }^{26}$

O orgulho, a dignidade, enfim, a constituição da representação de si é percebida por Isaías como fruto de um "ambiente artificial". Esse desencontro no romance está agravado pelo fato específico da cor da pele, que, no ambiente da família e da pequena cidade, entre ocupações simples e despretensiosas, não se apresenta como problema para o jovem. O sentimento de si como indivíduo digno, abonado pelos méritos da inteligência, essa espécie de individualismo de estufa, choca-se com uma lógica social que simplesmente o desconhece. A passagem pela delegacia é mais um degrau para baixo na visão que Isaías tem de si mesmo como um igual, como um indivíduo digno ou como um cidadão ("meus direitos ao Brasil" e a um "tratamento respeitoso"). Isaías é preso por desacato, por insistir em declarar-se estudante e reagir ao ser chamado de gatuno. Horas depois, é solto pelo delegado já mais brando, sem processo, sem justificativa. "Esses arrependimentos, essas voltas atrás são freqüentes e fatais no modo de agir das nossas autoridades". ${ }^{27}$

À noite, amargando a revolta contra o dono do hotel, que provavelmente o apontara como suspeito, Isaías junta forças para prosseguir. Talvez não fosse o mundo que estivesse fechado para ele ou que não o deixasse passar, talvez fossem seu "sangue covarde", seus "defeitos de caráter", que lhe amontoavam obstáculos à frente. "Não seria tolice, pusilanimidade escondida fazer repousar a minha felicidade na presteza com que um qualquer deputado atendesse um pedido de emprego? [...] As condições de minha felicidade não deviam repousar senão em mim mesmo". ${ }^{28}$ Agora, de fato, entra em teste o indivíduo sozinho no mundo. O futuro doutor decide começar de baixo e procurar um emprego humilde. Lê no jornal um anúncio para entregador de pão e, antes de atender-lhe, prepara-se psicologicamente, convence-se de que não havia mal no trabalho humilde, ainda mais que "era desconhecido, sem família, sem origens...". Se vencesse depois, não teria do que se envergonhar. ${ }^{29}$ Depois de toda essa preparação, Isaías vai até alegre em busca do emprego. Mas aqui o degrau para baixo é ainda mais profundo. Quando ele se apresenta ao dono da padaria para o emprego, o homem examina-o, diz-lhe bruscamente "não me serve" e volta-lhe as costas. Esse episódio liquida o jovem estudante, encerra as expectativas de vencer pela inteligência, de conquistar por si mesmo as condições de sua felicidade. "Naquela recusa do padeiro em me admitir, eu descobria uma espécie de sítio posto à minha vida. Sendo obrigado a trabalhar, o trabalho era-me recusado em nome de sentimentos injustificáveis". ${ }^{30}$

\footnotetext{
${ }^{26}$ Idem, ibidem, p. 110.

${ }^{27}$ Idem, ibidem, p. 122.

${ }^{28}$ Idem, ibidem, p. 124.

${ }^{29} \mathrm{Idem}$, ibidem, p. 127.

${ }^{30}$ Idem, ibidem, p. 127, grifo meu.
} 
Como se viu, um "senso de dignidade", ligado sobretudo ao intelectualismo, exige de Isaías toda uma preparação interior para conformar-se com a ocupação de pessoas humildes, como a de sua mãe, por exemplo. Ele se prepara para ser aceito, mas não para não sê-lo. De qualquer forma, antes e depois, sua visão do trabalho é ruim, está naquele polo da vida do qual ele quer fugir pela atividade intelectual. O orgulho de estudioso e inteligente coloca Isaías numa posição imaginariamente mais alta, ombreando com a posição ideológica da elite brasileira, para quem o trabalho apresenta-se como obrigação injuriosa.

Assim como no episódio do Dr. Castro, Isaías revolta-se intimamente com a recusa do emprego, mas seus "sentimentos liberais" impedem-no de condenar particularmente o padeiro, em quem apenas se manifestava um sentimento geral. A abertura do capítulo seguinte, já quase na metade do livro, mostra o resultado até aqui dos insucessos do protagonista: "Aquele meu fervor primeiro fora substituído por uma apatia superior a mim. [...] A minha individualidade não reagia; portava-se em presença do querer dos outros como um corpo neutro; adormecera, encolhera-se timidamente acobardada". ${ }^{31}$

Sem mais grandes expectativas, Isaías entrega-se a uma vida à margem, ainda assim dependente. Sai do hotel, aluga um quarto com mais algum dinheiro enviado pela mãe e, por acaso, encontra um ex-colega de escola, empregado no escritório de um medalhão no Rio de Janeiro. Torna-se seu secretário e professor, em troca de salário exíguo e irregular. Nesse período, toma contato com a boêmia literária e revolucionária, da qual se ressaltam sobretudo a imaturidade e a incoerência. Abelardo Leiva, poeta e revolucionário que o introduzira na vida boêmia, era por exemplo anarquista e positivista. Isaías guarda distância de seus entusiasmos, mas de certa forma está ativo em observar, examinar, estabelecer pontos de vista críticos, ainda que caracterize esse período como de grande atonia: "Abandonara-me à miséria que a proteção de Agostinho Marques impedia que chegasse a ser declarada".32

A fragilidade de sua situação evidencia-se quando o colega e protetor viaja para o norte do país, para lá permanecer por três meses, período em que tem de vender suas roupas e outros objetos, ainda passar fome e depender de quem, aqui e ali, lhe oferecesse um jantar. Em resposta ao pedido de ajuda à mãe, recebe a notícia de sua doença, muito grave, já terminal: "Morria minha mãe! E via-a logo morta, muito magra, os círios, o crucifixo, o choro...." ${ }^{33}$ Lembra então de como pouco havia pensado nela nos primeiros meses no Rio e como, recentemente, a lembrança da mãe tornara-se frequente: "sua figura flutuava a meus olhos: magra, esquálida, com o corpo premido pelos trabalhos e tendo pelas faces aquelas manchas de fumaça entranhada...". ${ }^{34} \mathrm{E}$ embora Isaías quisesse envolver essa lembrança

\footnotetext{
${ }^{31}$ Idem, ibidem, p. 133.

${ }^{32}$ Idem, ibidem, p. 148.

${ }^{33}$ Idem, ibidem, p. 149.

${ }^{34} \mathrm{Idem}$, ibidem.
} 
no que nele havia de mais terno, embora recordasse com sofrimento sincero dos carinhos e cuidados maternos, é possível ainda perceber a distância, o medo de comungar do mesmo destino.

Nesse momento extremo, encontra casualmente no correio Gregoróvitch, com quem chegara a travar amizade logo depois de sua chegada ao Rio. O jornalista compadece-se de sua situação e o indica para um emprego de contínuo no jornal. A partir daqui, exatamente na metade do livro, Isaías entra em uma nova fase e o enredo retrocede para dar lugar à sátira. O motivo dessa alteração de registro ou de gênero não se deve apenas, como pretendo mostrar, a tendências pessoais do autor que teriam interferido na boa construção do romance. Essa alteração ocorre justamente porque Lima Barreto tem em vista, de maneira muito consequente, um modelo pregnante de romance (Dostoiévski, Balzac, Stendhal, Flaubert), com o qual tenta contar a história de um jovem mulato brasileiro, do início do século XX.

A possibilidade de que o romance, por um desequilíbrio entre tendências internas objetivas e subjetivas, possa converter-se em sátira está considerada algumas vezes em A teoria do romance de Georg Lukács. A primeira menção inserese numa discussão sobre a necessidade do autorreconhecimento ou da autossuperação da subjetividade, segundo o que os teóricos românticos chamaram de ironia. Era necessária uma cisão interna do "sujeito normativamente criador" em uma subjetividade que enfrenta o mundo e busca realizar nele os conteúdos de sua aspiração e em outra que rejeita a abstração pura e simples, compreende mundo e sujeito em seus limites, ou seja, não escamoteia a dualidade, mas é capaz de configurar uma unidade no condicionamento recíproco dos elementos alheios entre si. Essa unidade é formal e o alheamento de mundo interno e externo não é superado, mas apenas reconhecido como necessário, e o sujeito desse reconhecimento está tão submetido à lógica interna do romance quanto seus outros objetos: "Isso retira da ironia toda a superioridade fria e abstrata que reduziria a forma objetiva à sátira, e a totalidade, a um aspecto". ${ }^{35}$ Mais adiante no livro, tratando agora de uma de suas mais famosas tipologias, o romance da desilusão, o crítico húngaro reforça a visão da sátira como resultado possível num eventual desequilíbrio subjetivista da forma do romance. Na formulação lukacsiana, o romance da desilusão configura-se num tipo de relação inadequada entre alma e realidade, em que o mundo interior e os anseios espirituais são mais vastos que os destinos que a vida concretamente pode oferecer-lhe. Nesse tipo de romance, a subjetividade tende a reconhecer-se como única essencialidade e a buscar um máximo de continuidade. Essa busca resulta, entretanto, em descomedimento, em desrealização do mundo em estados de ânimo, logo desabonados pelo todo como nulidade reflexiva. Nessa situação, sujeito e mundo precisariam ser negados, pois a afirmação de cada um desses elementos perturbaria o equilíbrio das forças internas do romance:

\footnotetext{
${ }^{35}$ Lukács, A teoria do romance, op. cit., p. 75.
} 
a afirmação do mundo daria razão ao filisteísmo vazio de idéias, à obtusa capacidade de acomodação a essa realidade, e permitiria surgir uma sátira fácil e barata; e a afirmação inequívoca da interioridade romântica teria de suscitar uma volúpia amorfa de um psicologismo lírico, que se adora frivolamente e espelha-se com vaidade. ${ }^{36}$

No caso das Recordações, o equilíbrio está desde logo ameaçado porque o ponto de vista subjetivo interno é frágil, então a possibilidade de que o mundo "vazio de ideias" imponha-se é sempre grande. O indivíduo problemático lukacsiano pressupõe que um indivíduo tenha se constituído, com um grau razoável de autorrepresentação e confiança. Tanto que as Recordações buscam criteriosamente prover esses elementos: Isaías tem uma visão positiva de si mesmo, é encorajado pelo pai e pela professora, que lhe inculcam modelos coerentes com as necessidades de constituição do romance. Mas essa, como ele mesmo logo percebe, constitui-se em um meio artificial, fechado, fora de contato com o mundo real. Diferente, portanto, da individualidade dos heróis do romance europeu, por exemplo, que encarnavam valores sociais difundidos pela figura pregnante de Napoleão, ainda que irrealizáveis na prática. Por isso, para Isaías, os primeiros contatos com a vida concreta são tão arrasadores. Não são as suas qualidades intelectuais e morais, a capacidade de se haver com o assédio da necessidade ou da ganância que estão em primeiro plano, mas a de não ser simplesmente suprimido como indivíduo, entidade de forma alguma dada previamente, como possa parecer. E ele chega de fato a anular-se como individualidade, pela metade do romance, para ressurgir apenas algumas páginas antes do final.

Os problemas narrativos das Recordações vão esbarrar assim no que Ian Watt apontou como condição de existência do romance. O tratamento sério de pessoas comuns na literatura dependia de que essa sociedade valorizasse cada indivíduo e houvesse uma variedade de crenças e ações que despertasse o interesse do leitor. Essas duas condições estavam ligadas ao "vasto complexo de fatores interdependentes denotado pelo termo 'individualismo", ${ }^{37}$ ou seja, que toda a sociedade se organizasse sob o consenso da independência e autonomia do indivíduo. Em parte, a decisão de Isaías de ir estudar no Rio, a confiança na própria inteligência têm aí o seu ponto de partida, que não progride muito, porque logo se vai buscar o bilhete do coronel. Quando o Dr. Castro tenta instigá-lo a outras iniciativas, Isaías o confronta com o dado da realidade, que é a mediação onipresente do favor. Depois de algumas tentativas mais, a vida de nosso herói borboleteia de proteção em

${ }^{36}$ Idem, ibidem, p. 124-5.

37 "The novel's serious concern with the daily lives of ordinary people seems to depend upon two important general conditions: the society must value every individual highly enough to consider him the proper subject of its serious literature; and there must be enough variety of belief and action among ordinary people for a detailed account of them to be of interest to other ordinary people, the readers of novels. It is problable that neither of these conditions for the existence of the novel obtained very widely until fairly recently, because they both depend on the rise of a society characterised by the vast complex of interdepent factor denoted by the term 'individualism"' (cf. Ian Watt, The rise of the novel, London, Chatto \& Windus, 1967, p. 60). 
proteção. O traçado de suas ações, aliás bem poucas, e de sua vida nesse período faz a estrutura da narrativa tender para uma divisão em episódios (Dr. Castro, o delegado, o padeiro, a boêmia, o jornal, Loberant etc.), aproximando-a mais da forma da novela. A fragilidade de encadeamentos e causalidades internas, na história de Isaías, indica a falta daquelas condições apontadas por Watt, ou seja, a falta do variado conjunto de relações que a sociedade burguesa moderna colocara à disposição do romance europeu.

A predominância da sátira na segunda parte do romance também tem relação com a ordem de coisas consideradas por Ian Watt. Em carta a um amigo, Lima Barreto justifica a inclusão da sátira e, mais que isso, do roman à clef, nas Recordações, pela necessidade de combater a indiferença sobre seu livro de estreia. ${ }^{38} \mathrm{Tal}$ afirmação deve ter reforçado a ideia de enxerto, de superposição de registros, que simplifica o problema da unidade. À parte isso, a declaração ressalta a consciência do autor de que a história de Isaías, por si mesma, não interessaria aos leitores disponíveis, aos seus contemporâneos. Não deixa de ser curioso que Lima Barreto praticasse então o gênero que ressurgia com força no começo do século XX na Europa, em condições diversas. Na visão de recente estudo sobre o assunto, o roman à clef tinha feito parte do amplo movimento de renovação da ficção naquele período, reagindo ao realismo conservador do final do século XIX, apesar de ser em geral subestimado pela crítica. ${ }^{39}$ Mas Lima nem atenderia ao apelo da crítica contemporânea, em favor de um realismo "mais idealista", nem rejeitaria o realismo formal pela problematização das normas de representação e o ataque direto, ficando numa posição frágil de ambos os lados. Entretanto, o realismo europeu, naquele momento, vivia uma crise de credibilidade que tinha algo em comum com as oscilações do realismo de Lima, uma crise que passava pelo indivíduo. Para Adorno, era ideológica a intenção de contar a própria história, "como se o curso do mundo ainda fosse o da individuação". ${ }^{40} \mathrm{O}$ cotidiano da vida industrial negava tal pretensão, como entre nós a dependência. Os narradores de Lima Barreto e do romance realista criticado por Adorno, embora em temporalidades distintas, têm em comum o desencontro entre uma forma de narrar e o processo social em curso. Nesse sentido, são ideológicos.

O momento da verdade (para falar com Adorno), ou seja, da historicidade das Recordações, está justamente em que as dificuldades do modelo em lidar com a

${ }^{38}$ Trata-se de uma carta a Gonzaga Duque, escrita em 1909. Lima Barreto, Correspondência ativa e passiva, op. cit., t. I, v. XVI, p. 169.

39 "At its core, The Art of Scandal makes a simple claim with far-reaching consequences: writers throughout the early twentieth century revived the roman à clef as part of a large movement to renovate fiction by loosing it from the strictures of a conservative realism. [...] Yet the often chaotic and still resonant results of such experimentation have largely been ignored, repressed or condemned as inartistic and inauthentic. By developing a distinctive art of scandal, however, writers and readers found a way to resist aesthetic autonomization by working at the complicated nexus of coterie culture, the mass market, cultural analysis, and the courts of law" (cf. Latham, The art of scandal, op. cit., p. 19-20).

${ }^{40}$ Theodor W. Adorno, Notas de literatura I, trad. Jorge de Almeida, São Paulo, Ed. 34, Duas Cidades, 2003, p. 56. 
matéria brasileira terminam inscrevendo-se na forma, ao longo da narrativa, seja pela oscilação constante do gênero em direção à novela, seja pela predominância satírica da metade para o fim do romance. O problema de unidade aqui, como se viu, apresenta-se de maneira diferente do percebido em Senhora, com outros resultados, mas de certa maneira pela recombinação de elementos comuns ou afins. Lima Barreto, diferentemente de Alencar, fez também incidir sobre a população "peculiarmente brasileira", ou seja, os que não vivem os conflitos do enredo principal, as ideias liberais. A fidelidade ao modelo de romance, como vimos, empurrou para a sátira a representação crítica dessa esfera, depois da anulação do herói. Nos dois casos, a tentativa de manter-se fiel ao modelo e à realidade interfere significativamente na forma. Fico pensando que o êxito detectado por Antonio Candido em $O$ cortiço, que equaciona admiravelmente "a filiação a textos e a fidelidade a contextos" ${ }^{41}$ provavelmente se deve à pouca importância do indivíduo no romance naturalista. A noção de indivíduo é tão profundamente social (ou seja, pressupõe toda uma sociedade, como explica Watt) que seu mero transplante constitui-se em fonte de desacertos.

Enfim, como Lukács descreve, em A teoria do romance, a conformação do herói encaminha a narrativa para a sátira. ${ }^{42}$ Desaparece o polo positivo do herói que busca, ele também submetido à normatividade da forma, e permanece a visão

${ }^{41}$ Cf. Antonio Candido, "De cortiço a cortiço", in O discurso e a cidade, 2.ed., São Paulo, Duas Cidades, 1998, p. 123-52.

${ }^{42} \mathrm{Na}$ formulação de Northrop Frye para os gêneros, em Anatomia da crítica, o enredo do romance (que limita suas aventuras e atinge uma forma literária) englobaria os quatro mitos por ele considerados: romance (em sentido mais amplo e mais antigo), tragédia, ironia ou sátira e comédia. "Agon or conflict is the basys or archetypal theme of romance, the radical of romance being a sequence of marvellous adventures. Pathos or catastrophe, whether in triumph or in defeat, is the archetypal theme of tragedy. Sparagmos, or the sense that heroism and effective action are absent, disorganized or foredoomed to defeat, and that confusion and anarchy reign over the world, is the archetypal theme of irony and satire. Anagnorisis, or recognition of a newborn society rising in triumph around a still somewhat misterious hero and his bride, is the archetypal theme of comedy" (cf. Northrop Frye, Anatomy of criticism, Princeton, New Jersey, 1973, p. 192). Mais adiante, quando trata especificamente da sátira, o autor reforça a ideia de desaparecimento do heroico como constitutivo desse mito: "The figure of the low-norm eiron is irony's substitute for the hero, and when he is removed from satire we can see more clearly that one of central themes of the mythos is the disappearance of the heroic (Idem, ibidem, p. 228). As Recordações podem ser descritas nesse esquema: primeiro, a série de tentativas de Isaías de colocar-se na sociedade (agon); depois, o momento extremo em que se esgotam suas chances de sobrevivência, culminando com a morte da mãe (pathos); a acomodação de Isaías no mundo dissolvente do jornal (sparagmos); e, finalmente, o ressurgimento do herói pela consciência e a reconciliação com a figura da mãe (anagnorisis). Mostro a concordância geral do romance de Lima com o esquema estrutural proposto por Frye para enfatizar a presença forte de um modelo narrativo em sua composição. Também se reforça aqui a noção de que a sátira não é necessariamente um enxerto externo na estrutura romanesca. Os modelos de romance e sátira organizam-se em diferentes combinações de elementos intercambiáveis. No caso específico em estudo, a sátira pode autonomizar-se no romance por causa da matéria histórica representada, ela também uma forma, que interfere na organização dos elementos do modelo. 
abstrata do narrador que recorda, Isaías já maduro, como contraponto isolado. O estado de pobreza em que se encontrava o jovem, quando finalmente consegue o emprego no jornal, o predispõe a uma adesão sem restos que se estende até o deslumbramento. "De tal maneira é forte o poder de nos iludirmos, que um ano depois cheguei a ter até orgulho da minha posição. Senti-me muito mais que um contínuo qualquer, mesmo mais que um contínuo de ministro". ${ }^{43}$ Nessa condição, será observador passivo e arredio dos acontecimentos no jornal, que pouca ou nenhuma influência tem diretamente sobre sua vida. Em termos gerais, a importância do jornal na trajetória de Isaías é franquear-lhe o conhecimento de um mundo do qual ele está excluído: o mundo da política, dos negócios, da cultura, enfim, das elites do país.

Boa parte da representação literária da segunda parte, como se sabe, é roman à clef, ou seja, tem como referente imediato o jornal oposicionista Correio da manhã, de Edmundo Bittencourt, e algumas figuras importantes do meio intelectual da época, como Coelho Neto e João do Rio. Já foi discutida rapidamente, um pouco antes, a atitude subjacente a esse tipo de literatura, que aprofunda na sátira a tendência pragmática de intervir na vida presente. Gostaria apenas de reiterar que a sátira se estabelece no recuo do herói, impedido pelos obstáculos que encontrou ao longo do caminho, ou seja, mesmo vinculando-se a referentes externos, a sátira tem uma ordem de necessidade no romance, dadas as condições de partida, assim como terá adiante influência na posterior desilusão do herói, quando volta a se incompatibilizar com o mundo. Antes disso, o narrador já anuncia o resultado dessa experiência: "No meio daquele fervilhar de ambições pequeninas, de intrigas, de hipocrisia, de ignorância e filáucia, todas as cousas majestosas, todas as grandes cousas que eu amara, vinham ficando diminuídas e desmoralizadas". ${ }^{44}$

Talvez seja emblemático dessa diminuição um trecho no romance em que aparece novamente a figura de Napoleão, o modelo de grande homem apresentado pelo pai. Veiga Filho, o famoso literato, havia feito uma conferência sobre a batalha de Austerlitz e reclamava do jornal uma notícia a respeito. Como nenhum dos repórteres tivesse tempo naquele dia, o próprio conferencista escreve a notícia, a ser publicada anonimamente, e lida depois no jornal "como um elogio valioso, isto é, nascido de entusiasmo sem dependência com a pessoa":

Foi um duplo triunfo, terminava assim a notícia, de Veiga Filho e de Napoleão, o último grande homem que a nossa espécie viu, cuja grandeza e cujos triunfos aquele grande artista soube pintar e descrever, jogando com as palavras como um malabarista hábil faz com as suas bolas multicores. ${ }^{45}$

A distância entre o Napoleão da primeira parte e o da segunda traça o abismo percorrido entre o sonho de grandeza de Isaías e o encontro com a realidade e, em

\footnotetext{
${ }^{43}$ Lima Barreto, Recordações do escrivão Isaías Caminha, op. cit., p. 177.

${ }^{44}$ Idem, ibidem, p. 262.

${ }^{45}$ Idem, ibidem, p. 173.
} 
termos de narrativa, entre o ponto de partida em falso e o rebaixamento da realidade representada. Lúcia Miguel-Pereira tem razão quando reclama de amesquinhamento da vida. Entretanto, a sátira acerta um alvo preciso, que é a irrelevância do meio intelectual de sua época. Esse tipo de delírio do literato Veiga Filho devia mesmo acontecer a todo momento, como ainda hoje em meios intelectuais mais acanhados. O problema dessa forma é que o modelo continua pairando, preservado pela abstração do ponto de vista, sobre a comédia de erros. Tanto que Isaías, no fim, depois de tudo, ainda se angustia por não ter sido forte o suficiente para vencer todos os obstáculos. Em outras palavras, a forma do romance não atinge Napoleão, de maneira que, no final, a questão tivesse de ser outra, mais direcionada aos conflitos reais. São agruras inerentes à consequência com que Lima Barreto retomou a grande tradição crítica do romance europeu, procurando com ela diretamente tratar a matéria brasileira. Seria preciso que o romance estabelecesse, assim, outra normatividade, outro princípio de composição, diferentes daqueles trazidos com o modelo. ${ }^{46}$ Mesmo assim, talvez porque o romance vá adiante sem desviar das dificuldades formais e mobilize experiências muito presentes, é possível identificar lateralmente outra questão que se apresenta para Isaías e é relevante no conjunto de assuntos e formas do romance, como veremos logo à frente.

Também é digno de nota que o protagonista já tenha perdido suas energias quando chega a entrar em contato com a instituição que está, naquele momento, mais próxima da empresa capitalista moderna, que é o jornal opinativo, no modelo do Correio da Manhã. O jornal O Globo vive de sua venda de exemplares, sem nenhuma subvenção do governo, e tem uma linha de atuação que visa o grande público. Isso interfere na linguagem, no tratamento das matérias, na escolha dos assuntos etc. Por sua vez, a grande tiragem também favorece a manipulação do público e a conquista de uma significação política. ${ }^{47}$ Toda essa gama de interesses, razoavelmente variada, não tem uma interseção com a experiência de Isaías, que permanece seu expectador. A condição de contínuo o coloca em uma situação de quase invisibilidade, que só muda por obra do acaso, quando Isaías vai avisar a

${ }^{46}$ Para Roberto Schwarz, a viravolta machadiana para a fase madura implica abandonar os princípios de composição importados com o modelo, da maneira como o escritor pratica ainda na primeira fase de sua obra, e submeter a forma do romance a uma lógica capaz de fazer jus à gravitação das idéias no Brasil (cf. Roberto Schwarz, Um mestre na periferia do capitalismo: Machado de Assis, São Paulo, Duas Cidades, 1990; Idem, "A viravolta machadiana", Novos Estudos Cebrap, n. 69, p. 15-34, julho, 2004).

47 "Nisso é que se alicerçou o O Globo; foi nessa divisão infinitesimal de interesses, em uma forte diminuição de todos os laços morais. [...] Cada qual mais queria, ninguém se queria submeter nem esperar; todos lutavam desesperadamente como se estivessem num naufrágio. Nada de cerimônias, nada de piedade; era para a frente, para as posições rendosas e para os privilégios e concessões. Era um galope para a riqueza, em que se atropelava a todos, os amigos e inimigos, parentes e estranhos." O jornal participava do jogo pela manipulação política, "indústria" em que se continuou fazendo dinheiro à margem do código, após as aventuras do encilhamento (cf. Lima Barreto, Recordações do escrivão Isaías Caminha, op. cit., p. 190-1). 
Loberant, no bordel, do suicídio de um repórter. Pego em situação constrangedora, o diretor passa a prestar mais atenção no jovem humilde. Descobre então o bom nível intelectual de Isaías e oferece-lhe o cargo de repórter, pelo qual ele se esforça e luta, inclusive fisicamente. Mesmo no período em que atua na redação, nosso herói adapta-se sem maiores problemas e não se perturba propriamente pela superficialidade, rebaixamento, fisiologismo, a que o obriga o trabalho. Isaías não se distingue e até aprende com os colegas as artimanhas de redação. Outros colegas é que protagonizam conflitos com a forma de trabalho do jornal. Floc, o crítico literário, enfrenta a dificuldade crescente de escrever de improviso, sob a pressão da hora, e termina suicidando-se na redação. Também o revisor Lobo tem um fim trágico, pois a mania das regras gramaticais leva-o à loucura, principalmente num meio em que o purismo atrapalha. Embora haja muito de caricatural nos dois, eles são inadequados de uma maneira que Isaías não será, ou seja, na medida em que certas características pessoais ou idiossincráticas conflitam com as formas da racionalização burguesa. O suicídio de Floc é apreciado pelo narrador como contrapeso positivo à dissolvência do jornal, mas o caso isolado é claramente incapaz de se afirmar frente ao desmonte promovido pela sátira até ali.

O grande jogo do dinheiro e do poder aparece agora sim como forma dissolvente, da qual o jornal faz parte. Isaías também participa indiretamente como repórter e beneficia-se dele quando se torna o favorito e companheiro de farras do proprietário do jornal. A prodigalidade do chefe garante-lhe um período de vida cheio de consideração, dinheiro e mulheres. Apenas nessa situação, não na do trabalho em si, surge o sentimento de inadequação: "Eu sentia bem o falso da minha posição, a minha exceção naquele mundo" ${ }^{48}$ Para fugir à dependência completa, que lhe fere um resto de orgulho, recorre mais uma vez à mediação do favor e pede ao influente Loberant que lhe arranje com o ministro um emprego de escrivão no interior. Assim, em todo o romance, Isaías nada consegue por si mesmo, encenando, tanto na forma realista quanto na satírica, apenas o fracasso de seu desejo de autodeterminação.

A onipresença da proteção, numa obra que parte do indivíduo livre e digno, é tanto mais curiosa porque esse não é seu foco. A intenção das Recordações até o fim é mostrar que o consenso da sociedade sobre a incapacidade do negro ou do mulato mina a sua visão de si mesmo e a sua força interior. A história de Isaías é a prova desse consenso, mas vai adiante. Fragilizado, nosso herói é jogado sem salvaguardas nas várias peripécias da loteria do favor, de maneira que ora passa fome, ora vive na abastança, sem poder atribuir aos seus atos a boa ou a má fortuna, que está nas mãos de outros sujeitos (Dr. Castro, o delegado, Agostinho Marques, Gregoróvitch, Loberant).

Nessa chave, não é possível mesmo construir uma experiência de si. Mas, como venho indicando ao longo do artigo, o romance de Isaías constrói outra linha de conflito, não explícita, em que outra história se passa. Nela, Isaías sai de

\footnotetext{
${ }^{48}$ Lima Barreto, Recordações do escrivão Isaías Caminha, op. cit., p. 282.
} 
casa para traçar a trajetória de Napoleão, a do pai, e, como diria Walter Benjamin, a de todos os vencedores. Mas acaba percebendo que as pessoas o veem como à mãe. Em boa parte do romance, ele procura fugir desse destino, no qual não quer se reconhecer. Debruçado em sua janela, no quarto de cortiço, o contínuo do jornal observa os vizinhos com incompreensão e piedade: "Admirava-me que essa gente pudesse viver, lutando contra a fome, contra a moléstia e contra a civilização; que tivesse energia para viver cercada de tantos males, de tantas privações e dificuldades". ${ }^{49}$ Mas ele prospera, inesperadamente, torna-se protegido de um dos homens mais poderosos da República, em que se reúnem num só tempo as imagens do pai e de Napoleão. Nesse momento, entretanto, sente o "falso" e a "exceção" do lugar que ocupa. Decide desistir de tudo e até para isso precisa de Loberant. No fim do romance, sem ordem de tempo precisa, está o passeio à Ilha do Governador, com Leda, uma italiana, e o chefe. Lá os três entram pela mata até perderem a noção do caminho, e chegam a uma casa, que lembra a Isaías a sua, da infância: "Era o mesmo aspecto, baixa, caiada, uma parte de tijolos, outra de pau-a-pique". Logo a seguir, na venda, enquanto comem alguma coisa, vêm-lhe mais lembranças: "Fomos servidos em velhos pratos azuis com uns desenhos chineses e as facas tinham aquele cabo de chifre de outros tempos. À vista deles, dos pratos velhos e daquelas facas, lembrei-me muito da minha casa, e da minha infância". ${ }^{50} \mathrm{~A}$ travessia da volta completa o reconhecimento do herói:

Voltamos de bote para a ponta do Caju. Durante a viagem a angústia avolumou-se-me. As pás dos remos, caindo nas águas escuras, abriam largos sulcos luminosos de minúsculas estrelas agrupadas e todo o barco vogava envolvido naquele estrelejamento, deixando uma larga esteira fosforescente.

Lembrava-me da vida de minha mãe, da sua miséria, da sua pobreza, naquela casa tosca; $\mathrm{e}$ parecia-me também condenado a acabar assim e todos nós condenados a nunca a ultrapassar. ${ }^{51}$

Nesse final, Isaías ainda vê depois, da carruagem, uma mulher sendo levada por dois soldados. Reconhece nela a amante do Dr. Castro e, sem saber por quê, julga-se culpado por sua desgraça. As cogitações e angústias de Isaías concentramse na autoconsciência de sua fraqueza, adequadas ao enredo de primeiro plano. Elas desviam entretanto a atenção de outro reconhecimento, que Isaías não chega a formular, mas está no centro dessas últimas páginas: o reconhecimento de si mesmo na mãe e, a partir dela, com todos os vencidos (todos nós). Se estou certa, as Recordações conduzem uma outra linha de sentido, desenvolvida tenuemente, em que se trata do problema do intelectual brasileiro pobre, mulato, em sua formação e definição ideológica. O barco em que Isaías faz a travessia para casa voga entre as estrelas refletidas. A beleza desse romance desigual está na força de retirar algo para si, apesar de tudo, quer dizer, do meio de todas as inadequações, fazer

\footnotetext{
${ }^{49}$ Idem, ibidem, p. 223, grifo meu.

${ }^{50}$ Idem, ibidem, p. 287.

${ }^{51}$ Idem, ibidem, p. 287, grifo meu.
} 
cintilar uma questão relevante para o próprio destino. Para onde se vai com isso, fica em aberto.$^{52}$ Não por acaso, o romance termina com a mesma imagem que inicia o livro A teoria do romance de Lukács: "Antes de entrar, olhei ainda o céu muito negro muito estrelado, esquecido de que a nossa humanidade já não sabe ler nos astros os destinos e os acontecimentos". ${ }^{33}$

\footnotetext{
${ }^{52} \mathrm{O}$ romance deixa em aberto se o autorreconhecimento individual de Isaías terá alguma consequência, mas o problema proposto tem ressonâncias coletivas e históricas importantes, basta lembrar que as décadas seguintes promoveriam uma mudança forte de orientação intelectual, que incluiu o "desrecalque localista" dos anos 1920, o "sopro de radicalismo" do romance e da análise social dos anos 1930, uma crescente "ida ao povo" e a consciência crítica do subdesenvolvimento (cf. Antonio Candido, "Literatura e cultura de 1900 a 1945 (Panorama para estrangeiros)", in Literatura e sociedade, 8.ed., São Paulo, T. A. Queiroz, 2000, p. 109-38; Idem, "O significado de Raízes do Brasil", Prefácio (1967), in Sérgio Buarque de Holanda, Raízes do Brasil, 10.ed., Rio de Janeiro, José Olympio, 1977; Idem, "Literatura e subdesenvolvimento", in A educação pela noite \& outros ensaios, op. cit., p. 140-2; Idem, "A revolução de 1930 e a cultura", Novos Estudos Cebrap, São Paulo, v. 2 , n. 4, p. 27-36, abril 1984). Neste último ensaio, sobre os anos 1930, Candido refere-se especificamente à situação do negro: "a radicalização propriamente dita, crítica e 'progressista', teve como traços mais salientes, além da 'consciência social', a ânsia de reinterpretar o passado nacional, o interesse pelos estudos sobre o negro e o empenho em explicar os fatos políticos do momento. Quanto ao negro, é preciso mencionar a iniciativa cultural dos próprios 'homens de cor', que inclusive criaram então uma imprensa muito ativa, não raro ligada a organizações como a Frente Negra Brasileira" (Idem, ibidem, p. 32)

${ }^{53}$ Lima Barreto, Recordações do escrivão Isaías Caminha, op. cit., p. 289.
} 